\title{
Interesting Narratives: Kant, Equiano, and the Great Reset
}

\section{Shane Moran \\ OCID iD: https://orcid.org/0000-0002-4654-1705}

\begin{abstract}
This essay addresses the intersection of narrative, morality, and development. Kant's deliberation on the public use of reason is connected to his treatment of slavery. The debate around Kant's racism is set in the context of Equiano's anti-slavery writings and the struggle for justice. It is argued that the contradictions and stresses within Kant's theory of moral judgement can illuminate the strategy pursued by Equiano. Similarly, the weaknesses of Kant's treatment of slavery can be traced to affinities he shares with Equiano. This conjunction, I argue, sheds light on current mobilisations of human rights discourse within the context of the debate on globalisation. An identifiable and resilient narrative of human development, personal responsibility, and imagination forms a bridge from the past to the present. Whether this unpredictable legacy will carry us to a better future is what is to be judged.
\end{abstract}

Keywords: Kant, reason, slavery, Equiano, narrative, great reset, judgement, morality, economics

Actually, almost every single decision related to how best to deal with the pandemic could be reframed as an ethical choice, reflecting that, in almost all cases, human practices labour under moral considerations (Schwab \& Malleret 2020: 218).

According to Klaus Schwab and Thierry Malleret, once again we are at the crossroads and 'our collective imaginations' (189) are called forth ${ }^{1}$. I propose

1 'Simply put, what we expose as facts or opinions [Meinungen: views] are moral choices that the pandemic has laid bare. They are made in the name of 
to contribute to this ongoing debate by revisiting the issue of slavery. I focus on Immanuel Kant's reflections on morality and reason, and then consider his comments on slavery. This is counterpointed by a reading of Olaudah Equiano's case against slavery and the constraints on the public use of reason he confronted. The justification for the conjunction of Kant and Equiano is that the slavery debate was also a debate about morality, reason, and imagination. As such, it prefigures the current 'unprecedented opportunity to reimagine our world' (146), and offers a coordinate from which to contribute to 'the enlarged view necessary to connect the many different dots that provide the more complete picture the decision-makers desperately need' (24).

The appeal to morality and imagination recalls Kant's reflections on the moral point of view, human progress and world history. Claims to 'to build a new social contract that honours the dignity of every human being' (Schwab 2020a) echo the philosopher of humanity and human rights ${ }^{2}$. Howard Caygill (1989) has shown the intersection of moral philosophy and political economy that underlies the discourse of progress emphatically directed by practical efficiency and the common good. The realm of the harmony of private and public interests involves the interplay between imagination and understanding. This is what Kant called 'the aesthetic power of judgement' and it 'constitutes enlightenment proper' (1790: $161 \S 40$, note). Holding judgement up to reason and putting oneself 'in the position of everyone else' is 'a relation between understanding and imagination' (162). It is linked to the moral point of view, human development and world history: 'an art of political soothsaying about future changes in states' (Kant 1784a: 119).

Recall Kant's well-known mission statement: Use humanity, whether in your own person or the person of another as an end and not as a means. This injunction covers the human being and every rational being (who may not be human) and raises a host of questions. By whose criteria are we bound? Does the moral point of view consist of the panoramic overview or the view from the individual level? Who arbitrates, in the interest of humanity? How do you separate selfless duty and the self-interested inclination? By

what we think is right or wrong and therefore define us as who we are' (Schwab \& Malleret 2020: 187).

2 'Human rights discourse, which has been dominant since the end of the Second World War, is a discourse that stems fairly directly from Kant's moral philosophy' (Vial 2016: 24; and see Brennan 1997). 


\section{Shane Moran}

rational discourse, the exchange of views, subjecting the matter at hand to public scrutiny, is Kant's answer. And that process is always under threat:

after [those guardians who have kindly taken it upon themselves to supervise] have made their domesticated animals dumb and carefully prevented these placid creatures from daring to take a single step without the walking cart in which they have confined them, they then show them the danger that threatens them if they try to walk alone (Kant 1784b: 17).

With time running out, and progress and survival become one, am I not duty bound to push my agenda, for the good of all? When you have a choice between destruction or salvation you must be malicious or stupid (irrational) to question the terms of the choice ${ }^{3}$. Who wants to embrace their own enslavement? On 'a terrain propitious for conspiracy theories and the propagation of rumours, fake news, mistruths and other pernicious ideas' it has always been a matter of 'whom we trust' (Schwab \& Malleret 2020: 181). Dot connectors are as important as ever"

Fear of global enslavement under the boot of corporate masters permeates a context in which moral appeals (the future of humanity) entwine with a narrative of progress (technology as fate; economics as destiny), and ruminations on world government. Those who fear politics is becoming no more than the administration of bare human life, a purely biological condition, perceive 'a narrative of dehumanisation' (Dodsworth 2021: 64). With censorship and demonisation rife, the mobilisation of public opinion is at stake: 'To be silenced and to be silent may be two very different things' (Drescher 1994: 140). If the recalibration of individual freedom and national sovereignty was to lead to one world government and a world digital currency, who would hold the planetary archons accountable? ${ }^{5}$

3 'Doing nothing, or too little, is to sleepwalk to ever-more social inequality, economic imbalances, injustice and environmental degradation' (Schwab \& Malleret 2020: 244).

${ }^{4}$ See Freeman and Kagarlitsky (2004: 29); Jameson (2005: 384-392); Satia (2008); and Losurdo (2019: 790).

5 'The archons are first of all the documents' guardians. They do not only ensure the physical security of what is deposited and of the substrate. They 
Are we back (if ever we left it) to a world of wire-pullers and conspirators? Or are those fixating on a connection between globalisation and late modern coloniali-sation simply lacking 'a new collective and moral consciousness based on a shared sense of destiny' (Schwab 2016: 134)?

One way of approaching these questions is to clarify concepts and explore analogous situations.

Kant and Equiano offer the opportunity to reflect on the origins of modern human rights discourse that is itself bound up with narratives of origin and progress. As Schwab and Malleret have reminded us 'narratives drive our behavior' (2020: 207).

Firstly. I would like to take up the thread of moral considerations and the public use of reason.

\section{I}

Those who believe they are surrounded by enemies everywhere ... are so often astute at interpreting what others do naturally as aimed against them ... in which the mind is held in suspense by means of analogies that are confused with concepts of similar things, and thus the power of imagination, in a play resembling understanding ... (Kant 1798a: 320).

The Groundwork of the Metaphysics of Morals (1785) analyses the good will necessary for moral action. The capacity of the will is intertwined with capacity for self-destruction. For example, consider the person for whom things are going well contemplating those who have to contend with great hardships. He could help them, but he thinks: 'what is it to me? let each be as happy as heaven wills or as he can make himself' (1785: 75).

Kant comments that such a viewpoint does not threaten the survival of the human race, and is 'even better than when everyone prates about sympathy and benevolence and even exerts himself to practice them occasionally, but on the other hand also cheats where he can, sells the right of human beings or otherwise infringes upon it' (1785: 75). Yet, this image

are also accorded the hermeneutic right and competence. They have the power to interpret ...' (Derrida 1996: 2). 


\section{Shane Moran}

of self and world self-destructs because indifferentism, however understandable as a conclusion drawn from contemplating the hypocrisy abroad in the world, does not transcend the situation from which it recoils. It is not simply that one might need the sympathy and help one denies to others, for selfinterest is not moral. Rather such scepticism rests on a naïve accommodation with things as they are, a kind of opportunistic, wilful lack of will. Cynicism is forgetfulness of the fact that just as the will to preserve is not entirely alien to the will to destroy, so too is the preservation of integrity dependent on contrast with chaos and night. Moralising, disgusted would-be resistance is really dependency.

Put another way - and to sidestep for a moment the whiff of sanctimony that invariably hangs about lectures on morality - scepticism is not simply opposed to naïve dogmatism. From a perspective that is not above either scepticism or dogmatism, but rather knowingly immersed in their mutually reinforcing co-implication, there is a passage through the conclusion that all has been tried and found wanting. In this understandable recoil, according to the Critique of Pure Reason, 'after all paths (as we persuade ourselves) have been tried in vain, what rules is tedium and complete indifferentism, the mother of chaos and night' (1781/7: Ax, 100). Beyond disgust, this tedium spirals into despair and nihilism. And yet this intellectual (and moral) pit is also 'the origin, or at least the prelude, of ... incipient transformation and enlightenment'. The image carefully built up in people's minds will destroy the image, and this destruction is necessary for transformation and enlightenment (see Lyotard: 2009: 7).

The Critique of Pure Reason describes 'a new phenomenon of human reason' (B434, 460). This novel illusion of reason is a mark above 'the slumber of an imagined conviction', not least because of its obviousness: 'one does not need to ponder or to lay artificial snares'. The phenomenon is out in the open, and a moment's reflection reveals its operation. It exists and exerts a mystifying influence on the use of reason, or more precisely, it results in deadlocked debate. It 'leads reason into the temptation either to surrender itself to skeptical hopelessness or else to assume an attitude of dogmatic stubbornness, setting its mind rigidly to certain assertions without giving a fair hearing to the grounds for the opposite'. On the one side toxic scepticism, suspicious of all authority and claims to truth - always demanding incontrovertible proof before credibility is granted - and on the other, the repetitive assertion of authority and the silencing of debate. As Kant puts it 
in his lectures on logic, it seems that '[i]magination and understanding are two friends who cannot do without one another but cannot stand one another either, for one always harms the other' (1792: 447).

Kant offers a mini-narrative of reason's progress in terms of the topographical and territorial imagery he favours: 'In the beginning, under the administration of the dogmatists', the 'rule' of metaphysics 'was at first despotic. Yet because her legislation still retained traces of ancient barbarism, this rule gradually degenerated through internal wars into complete anarchy; and the skeptics, a kind of nomads who abhor all permanent cultivation of the soil, shattered civil society from time to time' (Aix, 99; and see Lyotard 2009: 28-29). The new phenomenon produces a vicious, selfconfirming circle, a stasis of sceptical hopelessness and dogmatic stubbornness that too often degenerates into recrimination and intolerance: 'Either alternative is the death of healthy philosophy, though the former might also be called the euthanasia [Euthanasie] of pure reason' (B434, 460).

The spectacle of the death of reason is difficult to prevent since in such a context every intervention is met with dogmatism and/or corrosive scepticism; with the demand that you prove you are not lying or delusional. Accusations of being hoodwinked or complicit abound, personal invective flourishes, and reason chokes in the swamp of irrationality and self-interest. In this spirit, one can wonder on what grounds Kant makes distinction between the constituent elements of his new phenomenon, a distinction which itself smacks of dogmatism. After all, as he argues in the name of reason, no one is above suspicion. The very definition of this phenomenon already evinces an interpretation that delimits the area of enquiry, framing the issue in a way that is always open to question (see Serequeberhan 2010).

To put it in other terms, we might say that Kant's diagnosis presumes, and endorses, a specific etiology regarding more than the causes and results of the novel disease of reason he identifies. It also raises the subject of his own reasoning - the origin of his own account of origination that Kant tries to make explicit without falling into abyssal recursivity (which typically invites either scepticism or dogmatism, or both). I must make a judgement, a decision about decision, and in the process align myself. The challenge is to avoid scepticism and dogmatism but we know that any decision is open to being characterised as one or the other, for there is always 'a certain degree of misology, that is hatred of reason' (1785: 51), in the air. It is up to each individual to reanimate the spirit of reason at the expense of 
entrenched bigotry or corrosive despair, on behalf of a reason always dead, always coming back to life.

Kant's invocation of the defensive anxiety of legitimate possession has proven prophetic as he has come under increasing criticism for his handling of the concept of race (see, for example, Eze 1995 and 1997). This issue is seen as historically important in determining the complicity of European modernity and racism, and relevant to contemporary discussions of human rights and the universalisation of western ethico-political norms. At issue is not only the legitimacy of the claim to philosophical authority, but also the tendency of historically determined ideas of progress and development to serve the ends of self-interest. The case of slavery brings these issues into focus.

\section{II}

It is not enough that we ascribe freedom to our will on whatever ground, if we do not have sufficient ground for attributing it also to all rational beings (Kant 1785: 95).

Regarding slavery, how do things stand in terms of morality and reason? Kant, so fond of making examples of others, is an interesting example regarding this question. 'On the Use of Teleological Principles in Philosophy' (1788) sets forth Kant's reflection on the subject of slavery and the nature of the human race. The subject is the 'entire original predisposition' of the human species who were fit for all climates and adapted themselves to each variation, and so survived. Those that did not, did not:

Thus, there was no need for a special arrangement to bring them to a place where their special arrangement fit. Rather wherever they went by chance and continued their generation over long periods of time, there developed this germ for the region of the earth to be found in their organization, which made them fit for such a climate (1788a: 208).

The development of predispositions depended on the places, and on the pre- 
disposition to have predispositions (adaptability). But what happens 'in the case of a second transplanting' (208)? What of the 'inner purposiveness' (209) when it is quite clear that transplanted people do not uniformly adapt to their new climate and become like the indigenous inhabitants? To be more specific:

And where have Indians and Negroes attempted to expand into northern regions? - But those who were driven there have never been able to bring about in their progeny (such as Creole Negroes, or the Indians under the name of gypsies) a sort that would be fit for farmers or manual laborers (1788a: 209).

The 'inner purposiveness' that has 'provided for their preservation' apparently meets its limit. And, we might add, so too does the nicety of abstract concepts and the pleasure of formalism ${ }^{6}$.

Moving to individual instances, however typological, is to step into a territory strewn with snares. They haven't gone native, is the proposition, and neither have their children. Kant adds a clarificatory note:

The last remark was not put forward here in order to prove something but is nevertheless not insignificant. In Hr. Sprengel's Contributions ( $5^{\text {th }}$ Part, pp.287-92), a knowledgeable man, adduces the following against Ramsay's wish to use all Negro slaves as free laborers: that among the many thousand freed Negroes which one encounters in America and England he knew of no example someone engaged in a business which one could properly call labor; rather that, when they are set free, they soon abandon an easy craft which previously as slaves they had been forced to carry out, and instead become hawkers, wretched innkeepers, lackeys, and people who go fishing

6 'It is easier for us, with two hundred years' hindsight, to see such contradictions in Kant himself (or in other eighteenth- or nineteenth-century) thinkers than to see them in ourselves. In that sense, it is dangerous for us to focus on Kant's (now obvious) errors about issues of race or gender, as if we thought that we ourselves might be immune to similar criticisms by future philosophers reflecting on our views' (Wood 2008: 11). Alternatively, one can simply ignore these issues altogether (see Guyer 2016). 
and hunting, in a word, tramps. The same is to be found in the gypsies among us (1788a: 209, note).

Kant's reference here is to M.C. Sprengel's Beiträge zur Völker und Länderkunde (Contributions to the Study of Peoples and Countries) which the editors of the Cambridge edition of Kant's works explain 'contains and essay in German "Notes on Ramsay's work on the treatment of the Negro slaves in the West Indies", which refers critically to the work of James Ramsay, former pastor on the island St. Kitts' (Zöller \& Louden 2007: 510).

It seems that Kant read a summary of James Tobin's Cursory Remarks upon the Reverend Mr. Ramsay's Essay on the Treatment and Conversion of African Slaves in the Sugar Colonies (1784) in Sprengel ${ }^{7}$. Read and approved of a pro-slavery argument attacking abolitionist James Ramsay. Ramsay, along with Grenville Sharp and Thomas Clarkson, are 'named with praise and honour' by Equiano in the final pages of The Interesting Narrative of the Life of Olaudah Equiano, or Gustavus Vassa, the African. Written by Himself (1789) as 'our approved friends, men of virtue, are an honour to their country, ornamental to human nature, happy in themselves, and benefactors to mankind!'.

Was Kant, the renowned excavator of foundations, not only deficient in understanding, never mind empathy? It is not as if the belief that former slaves lost their desire to work when freed amounted to denying that the former slave is 'a being that has reason and a will' (1785: 50) - on the contrary, aversion to work after enslavement can be taken as a sign of reason and will. Could Kant not see that the pro-slavery case arose from 'a selfseeking purpose' (53) and 'merely for purposes of self-interest' (55)? Was his lack of resistance to the pro-slavery case because he was blind to the 'empirical inducements' (64) and 'our covert incentives' (61)? Suppose Kant's aside on slavery was not 'an intentionally untrue declaration' (1797a: 612). It was not a lie $^{8}$ but more of an error arising from ignorance: no harm was intended. Since it was not a legal declaration, taken under oath, it has not harmed 'humanity generally, inasmuch as it makes the source of right

${ }^{7}$ See Bernasconi on James Tobin (2019: 28; and 2002: 148-149).

8 'A human being who lies has no character at all, and if he has anything good in him, this is merely due to his temperament ... The withdrawal of respect is the only appropriate punishment for lying' (Kant 1803: 471). 
unusable' (612). Did he lack good will to people of colour because of susceptibility to 'certain subjective limitations and hinderances' (1785: 52)? ? $^{9}$ Does Kant himself demonstrate the contamination of reason with 'empirical motives', 'the actions and conditions of human volition generally, which for the most part are drawn from psychology' (46)? In short, can we trust Kant's judgement?

The endorsement of a central justification of slavery does not to accord with the universal principle of right: 'Any act is right if can co-exist with everyone's freedom in accordance with a universal law, or if on its maxim the freedom of choice of each man can coexist with everyone's freedom in accordance with a universal law' (1797b: 387). Moreover 'whoever hinders me in it [i.e., coexisting with the freedom of everyone in accordance with a universal law] does me wrong; for this hindrance (resistance) cannot coexist with freedom in accordance with a universal law' (387). On the matter of slavery, and race, it seems that Kant, by his own moral standard, was in the wrong ${ }^{10}$.

Beyond the question of Kant's good will, the issue of slavery raises issues that are often passed over in discussions of Kant and racism. As well as human types, classification, potential and destiny, slavery foregrounds the economic aspect at work in the discussion of morality and human progress.

9 'Though Kant never directly defends the institution of black slavery, in a footnote he quotes with approval the observations of a German opponent of its abolition, who claims that freed slaves generally lose the laboring skills they formerly possessed' (Wood 1999: 8). Wood claims that Kant doesn't deny moral status to any human being on the basis of race (338-9 note 4). Kant does mention the slave trade in The Conflict of the Faculties where the English parliamentary debate on slave trade crops up as an example of a political diversion or disguise. The apparent tension between the monarch and some of those acting as representatives of the people regarding the legitimacy of the slave trade conceals the fact that monarch's will is decisive, despite the British claim to have moved from absolute monarchy to constitutional monarchy (see 1798b: 163).

10 'Even by the standards of his own time, let alone by those of our time, Kant was not always entirely enlightened, especially when his views (as on matters of race) could only be second-hand because of the social and geographical limits of his own experience' (Guyer 2007: 21). 


\section{Shane Moran}

Freedom is linked to what 'one could properly call labor'. Productivity and social utility, price rather than dignity, are not exterior to morality and its presupposition, freedom. And we might add, property. Although Kant does not defend slavery ${ }^{11}$ he does endorse the importance and value of labour:

The same author [Sprengel] notes on this matter that that it is not the northern climate that makes Negroes disinclined for labor. For they would rather endure waiting behind the coaches of their masters or, during the worst winter nights, in the cold entrances of the theatres (in England) than to be threshing, digging, carrying loads, etc. (1788a: 209 note).

The problem with freedmen (and women) is that 'when they are set free, they soon abandon an easy craft which previously as slaves they had been forced to carry out'. Free of direct coercion, they become lackeys (menials) and tramps (negligent or even hostile to fixed property). In the case of former slaves the price of freedom threatens the economy and hence the stability of society. Kant faithfully relays Tobin's central argument against the practicality of manumission on the grounds that there is no evidence that freedmen gravitate to 'any laborious task' (Tobin 1785: 117) ${ }^{12}$. Tobin also counters the hypothesis 'that their choice of employment in England may, in

${ }^{11}$ For Kant slavery devalues humans to a market price: 'A seafarer listened to the dispute in a society led by scholars over the rank of their respective faculties. He decided it in his own way, namely: how much would a human being he had captured bring in for him at the sale in the marketplace in Algiers?' (1798a: 390).

12 'The great number of negroes at present in England, the strange partiality shown to them by the lower orders of women, and the rapid increase of a dark and contaminated breed, are evils which have long been complained of, and call every day more loudly for enquiry and redress' (Tobin 1785: 118, note). Endorsing Tobin's critique of Ramsay, Gordon Turnbull espies Ramsey '[a]t the head of those fanaticks, who set themselves up as reformers, and have the presumption to think themselves wiser than the rest of mankind' (1786: 17-18). The truth is 'that the negroes are much happier than peasants in most parts of the world', and 'that many of the free negroes in that part of the worlds are far less happy than slaves' $(32,33)$. 
some measure, be influenced by the climate' by citing evidence from Jamaica and St. Vincent that former slaves refuse 'to labour in the field for hire' (119).

From this information Kant looks for causes in human types and their predispositions:

Should one not conclude form this that, in addition to the faculty to work, there is also an immediate drive to activity (especially to the sustained activity that one calls industry), which is independent of all enticement and which is especially interwoven with certain natural predispositions; and that Indians as well as Negroes do not bring anymore of this impetus into other climes and pass it on to their offspring than was needed for their preservation in their old motherland and had been received from nature; and that this inner disposition extinguishes just as little as the external one (1788a: 209 note).

Going one step further than Tobin, Kant is able to combine an argument from environment with the theorisation of certain natural dispositions. Indians as well as Negroes embrace their own minority and subordination ${ }^{13}$. It seems that the the discourse of human rights, the primacy of freedom and rationality, and the necessity of respect, can coexist with the pro-slavery principle of economic productivity and force. No surprise in that, you might think, but if this nexus cannot be jettisoned in the fight for freedom, how might the exploitation of its ambivalence be countered?

What Kant shares with the pro-slavery camp is as striking as what the abolitionist argument shares with $\mathrm{Kant}^{14}$.

${ }^{13}$ Macrobius Theodsius: 'Assuredly no form of slavery is more shameful than that which is self-imposed'. This quotation from Macrobius concludes Gilbert Francklyn's An Answer to the Rev. Mr. Clarkson's Essay, etc., (1789: 243). For the continuation of this bitter debate see William Hannibal Thomas (1901: 338-339).

14 'This problem [the achievement of civil society through unsociability] is at the same time the most difficult and the latest to be solved by the human species. The difficulty which the mere idea of this problem lays before our eyes is this: the human being is an animal which, when it lives among others of its species, has need of a master. For he certainly misuses his freedom in regard to others of his kind; and although as a rational creature he wishes a 
This, I will argue, points to an underlying affinity that facilitates the slippage from asserting the primacy of human freedom (autonomy) to embracing the necessity of coercion and domination (heteronomy). The moral debate about slavery is inseparable from the narrative of development, and Equiano's The Interesting Narrative of the Life of Olaudah Equiano, or Gustavus Vassa, the African. Written by Himself. shows the switches and relays of the discourse of progress.

\section{III}

That part of Africa, known by the name of Guinea, to which the trade for slaves is carried on, extends along the coast above 3400 miles, from the Senegal to Angola, and includes a variety of kingdoms. Of these the most considerable is the kingdom of Benen, both as to extent and wealth, the richness and cultivation of the soil, the power of its king, and the number and warlike disposition of the inhabitants (Equiano 1789: 5$)^{15}$.

Equiano's credibility as 'the African' is interwoven with the case against slavery. The autobiographical mode foregrounds the issue of morality and

law that sets limits to the freedom of all, his selfish animal inclination still misleads him into excepting himself from it where he may. Thus, he needs a master, who breaks his stubborn will and necessitates him to obey a valid will with which everyone can be free. But where will he get this master? Nowhere else but from the human species. But then this master is exactly as much an animal who has need of a master' (Kant 1784a: 113).

15 'That part of Africa whence the negroes are brought, commonly known by the name of Guinea, extends along the coast, in the whole, between three and four thousand miles. From the river Senegal, (seventeen degrees north of the line) to Cape Sierra Leona, it contains seven hundred miles. Thence it runs eastward about fifteen hundred miles, including the Grain-Coast, the IvoryCoast, the Gold-Coast, and the Slave-Coast, with the large kingdom of Benin' (Wesley 1744: 4-5). 
the tearing asunder of 'all the tender connexions' (Equiano 1789: 3) ${ }^{16}$, both for the authorial subject and the reader.

Equiano describes his homeland: 'This kingdom is divided into many provinces or districts: in one of the most remote and fertile of which, called Eboe, I was born, in the year 1745, in a charming fruitful vale, named Essaka' (5-6) ${ }^{17}$. He remarks the government and administration of justice of his homeland, and gives examples of the punishment for 'kidnapping' and '[a]dultery' which 'was sometimes punished with slavery or death' (6). Marital relations deem the wife 'the sole property of her husband' (6) - 'nor do I remember to have ever heard of an instance of incontinence amongst them before marriage' (9) - and domestic relations are sketched. Any other property is common property for in this 'uncommonly rich and fruitful' land '[a]ll our industry is exerted to improve those blessings of nature':

As our manners are simple, our luxuries are few .... Our manner of living is entirely plain .... Agriculture is our chief employment; and every one, even the children and women, are engaged in it. Thus, we are all habituated to labour from our earliest years. Every one contributes something to the common stock; and as we are unacquainted with idleness, we have no beggars. The benefits of

${ }^{16}$ See J. Philmore on 'this bond of humanity, that is the foundation of all other particular connexions between men' (1760: 9). Clarkson quotes Anders Sparrman's A Voyage to the Cape of Good Hope (1785) on the enslavement of Hottentots at the Cape: 'in cold blood they destroy the bands which nature has knit between their husbands, and their wives and children, \&c' (Clarkson 1788: 48). Sparrman joined Cook's second arctic voyage as assistant to Johann and George Forster.

${ }^{17}$ Wesley quotes Andrew Brue, who lived in Senegal for sixteen years, on the area's 'fruitfulness': 'The farther you go from sea, the more fruitful and well-improved is the country ... the land so well cultivated' (1744: 5). Wesley concludes: 'The Gold-coast and Slave-coast, all who have seen it agree, is exceeding fruitful and plentiful ... is one of the most fruitful as well as the most pleasant countries in the known world ... Such is the country from which the Negroes are brought' (5). Shortly before his death Wesley read Equiano's Interesting Life with approval without remarking on the similarity between their two texts (see Wesley 1791: 265). 
such a mode of living are obvious $(7)^{18}$.

From government, law, domestic relations, food, and labour we move to religion: 'As to religion, the natives believe that there is one Creator of all things', and 'are extremely cleanly ... and therefore we had many purifications and washings; indeed almost as many, and used on the same occasions, if my recollection does not fail me, as the Jews' $(9-10)^{19}$. Equiano reflects on his account:

Such is the imperfect sketch my memory has furnished me with of the manners and customs of a people among whom I first drew my breath. And here I cannot forbear suggesting what has long struck me very forcibly, namely, the strong analogy which even by this sketch, imperfect as it is, appears to prevail in the manners and customs of my countrymen and those of the Jews, before they reached the Land of Promise, and particularly the patriarchs while they were yet in that pastoral state which is described in Genesis - an analogy, which alone would induce me to think that the one people had sprung from the other. Indeed, this is the opinion of Dr. Gill, who, in his commentary on Genesis, very ably deduces the pedigree of the Africans from Afer and Afra, the descendants of Abraham by Keturah his wife and concubine (for both these titles are applied to her). It is also conformable to the sentiments of Dr. John Clarke,

18 Wesley describes the mode of 'government' and the administration of justice, and 'the simplicity of their dress and manners': 'they are remarkably industrious' (1744: 7). 'They punish murder and adultery severely; very frequently with death. Theft and robbery are punished by a fine proportionable to the goods that were taken. - All the natives of this coast, though heathens, believe there is one God ... we may leave England and France, to seek genuine honesty in Benin, Congo, or Angola' (7-9). Anthony Benezet quotes Peter Kolben (Kolb) on the Negro inhabitants of the Cape of Good Hope, their government administration of justice, mentioning punishments for 'Adulteries and Robberies' and 'their Stricktness and Celerity in the Execution of Justice' (Benezet 1762: 21-23).

19 Senegal 'is very fruitful and populous ... They are a clean People, especially the Women' (Benezet 1762: 74-76). 
formerly Dean of Sarum, in his Truth of the Christian Religion: both these authors concur in ascribing to us this original (11-12).

Equiano's claim that for a 'strong analogy' between 'the Israelites in their primitive state' (12) and contemporary Africans lacks the textual authority to which he appeals ${ }^{20}$. The only 'corroboration' (120) is 'the imperfect sketch my memory has furnished me with of the manners and customs of a people among whom I first drew my breath' (11). This is why the debate around Equiano's origin, his claim to have been born in Africa circulate with such intensity ${ }^{21}$. However, while the threat to the evidentiary value of the account of Africa and the middle passage is obvious, the value of Equiano's account is not thereby vitiated. The case against the slave trade does not fall with the insecurity of the opening two chapters.

Equiano's motive is, he declares in the dedication, to become 'an instrument towards the relief of his suffering countrymen' and if his account 'in the smallest degree promotes the interests of humanity, the ends for which it was undertaken will be fully attained' (5). Departing from the moral absolutism that is often a feature of abolitionist texts, there is a complexification and ambivalence. Forgoing the ritualised citation of familiar sources

${ }^{20}$ Regarding Equiano's references to John Gill's Commentary on Genesis and John Clarke's translation of Grotius, The Truth of the Christian Religion (1711), Sylvester A. Johnson has noted that 'none of these commentators actually claim that Africans are descendants of ancient Jews; the claim is Equiano's exclusively' (2015: 147). Johnson's judgement that '[ $\mathrm{t}]$ he degree to which Equiano handles his sources to derive an interpretation is uniquely his own' (149) is more deflection than analysis. See also the striking similarity between Lawrence Harlow's An account of the conversion of an Indian, in a letter to a friend (1774) and chapter 10 of Equiano's The Interesting Narrative. Equiano does mention 'a little book, entitled The Conversation of an Indian' (83).

${ }^{21}$ See Vincent Carretta (2005); John Bugg (2006); and Gloria Chuku (2013). Chinua Achebe: 'I have myself pinpointed to my own satisfaction and from the evidence in his text the village of his birth as Iseke' (2009: 74). 'His son, who is expert in bibliography, became assistant librarian to Sir Joseph Banks, and is also secretary to the commission for vaccination' (Gregoire 1808: 129; see also Armistead 1848: 239). 


\section{Shane Moran}

and testimony regarding slavery, Equiano pulls the focus onto himself, or rather, his self-creation (see Carretta 2005). I believe that this alternative aims to strengthen the abolitionist cause by a more modulated and uncomfortable appeal to imagination and compassion than had become standard within abolitionist rhetoric. The self-creation of Equiano, author and subject, narrator and reader of his own past, is also an attempt to create and shape a readerly sensibility and institute a moral economy that avoids the pitfalls of moralising ${ }^{22}$.

Although Equiano's warns on the first page that 'I offer here the history of neither a saint, a hero, nor a tyrant' (5), this abjuration sets the scene for complex manoeuvres that break the frame of condemnation and exoneration. It is not merely that Equiano knows that his narrative, with its derivateions, compromises and complicities, will not sustain a pose of moral sanctimony ${ }^{23}$. Choosing to work in the slave trade as a free agent means that there is not simple inside or outside. While the evil of the slave trade is never in doubt, the motives and actions of those caught within it - including slave owners, traders and survivors - are not judged programmatically. For example, the frequency with which Equiano adjudges his masters/owners to be 'very charitable and humane', such that 'I was very grateful' (41) is striking.

Whatever the strategic value of engaging his English audience with a variegated portrait of their fellow countrymen, this mode of presentation complicates the logic of jeremiad which aims at an inclusive and thoroughgoing condemnation of individual behaviour. There are exceptions and gradations of reprehensibility, and there is even virtue in the midst of complicity: 'he was to me a friend and a father' (64). But there is also, as if

22 Equiano's weaving of moralising humanism and business logic does not fit Ian Baucom's formula of the two distinct discourses of property active in the Zong trial: 'a contest between the speculative imagination of finance capital and the sentimental, romantic imagination of melancholy ... a formulaic melancholy ... and a formalized finance capitalism can sometimes operate not only as antagonists but as secret sharers in the philosophical discourse of modernity' (2005: 205).

${ }^{23}$ Equiano in combative mode taunting Tobin: 'Away with your narrow impolitic notion of preventing by law what will be a national honour, national strength, and productive of national virtue - Intermarriages!' (Equiano 1788: 218). 
by reflection, a range of moral judgement, or reserve of judgement, elicited here that encompasses the figure of Equiano himself. The perhaps questionable extension of charitable judgement on the actions of others, the refusal to treat them as a monolithic function of the slave economy, effectively preempts any absolute judgement on Equiano's voluntary participation in the slave trade following his manumission. The process of judgement Equiano's judgement, our judgment of him, and our reflection on the process of judgement - is foregrounded. The 'attempt to counteract the lies and slander invented by some Europeans to justify the slave trade' (Achebe 1964: 80) calls for self-reflection in addition to refutation.

Transporting slaves to Georgia, Equiano's ship runs aground on the Bahama Bank 'but the crew are preserved, principally by means of the author' (64). Striking a rock at night the captain orders the hatches nailed down to prevent twenty slaves from overcrowding the boat. Equiano refuses and all the slaves and crew are saved by his ingenuity. By putting his own life at risk he is able to save others. Guiding crew and cargo to an island, a new fear arises: 'On that part of it where we first attempted to land there stood some very large birds, called flamingoes: these, from the reflection of the sun, appeared to us at a little distance as large as men; and, when they walked backwards and forwards, we could not conceive what they were: our captain swore they were cannibals' (66). Equiano confronts the apparent cannibals and they 'took flight' (66). The story of the disaster weaves 'my guilty head' (65) with heroic vindication of the author's seamanship.

This image of self-sacrificing Equiano the slave trader is counterpointed by his participation in Doctor Irving's 'new adventure in cultivating a plantation at Jamaica and the Musquito Shore [present day Honduras]' (92). 'Our vessel being ready to sail for the Musquito shore, I went with the Doctor on board a Guinea-man, to purchase some slaves to carry with us, and cultivate a plantation; and I chose them all my own countrymen' (93). The extensive account of South American native life, in which he recalls 'a passage I had read in the life of Columbus' (94) ${ }^{24}$, is followed by his attempt to leave the Mosquito coast whereupon he experiences Crusoe-like adventures on barren inlets and islands and is repeatedly held against his will 'without judge or jury' (96). Threatened with

${ }^{24}$ The site of his and Dr Irving's enterprise, Cape Gracias a Dios (Equiano 1789: 93), was named by Columbus on his last voyage. 


\section{Shane Moran}

being sold into slavery and on more than one occasion threatened with death - 'Seeing this I got an axe ... having resolved in myself as soon as he attempted to put the fire in the barrel to chop him down that instant' (99) he meets his former business partner, Dr. Irving:

I now learned that after I had left the estate which I managed for this gentleman on the Musquito shore, during which the slaves were well fed and comfortable, a white overseer had supplied my place: this man, through inhumanity and ill-judged avarice, beat and cut the poor slaves most unmercifully; and the consequence was, that every one got into a large Puriogua canoe, and endeavoured to escape; but not knowing where to go, or how to manage the canoe, they were all drowned; in consequence of which the doctor's plantation was left uncultivated, and he was now returning to Jamaica to purchase more slaves and stock it again (99).

Following in the wake of slavers and colonialists, Equiano is both victim of, and participant in, what he condemns. Having abandoned his countrymen, and the place of manager taken by 'a white overseer', it unclear if Equiano was himself a black overseer-cum-manager. He does not address the question of his responsibility for the death of his countrymen, and the morality of his action and his narration is left for the reader to decide ${ }^{25}$.

Perhaps the thinking behind recounting such events is that while one may counter and hopefully defeat arguments for slavery by a polarising attack, such bifurcation does not facilitate understanding the moral economy of that trade. Grasping the dynamics of the trade may be necessary for bringing about its abolition, but grasping its exploitative, dehumanising essence must also include the fraying of categories. When Equiano castigates the slave traders his words implicate the reader too: 'Must every tender feeling be likewise sacrificed to your avarice?' $(21)^{26}$. We are at stake here and

25 Equiano's truthfulness regarding his involuntary and then voluntary collaboration with slave traders accords with Kant's principle that 'truthfulness (if he must speak) is an unconditional duty' (1797a: 614).

26 'How many Thousands of our harmless Fellow Creatures have, for a long Course of Years, fallen a Sacrifice to that selfish Avarice, which gives life to this complicated Wickedness' (Benezet 1762: 4). 
whether or not we sacrifice the sacrificers we will remain implicated, left in the wake of 'the inhuman slave trade' (108). Equiano's profession of complicity pushes onto the reader the responsibility for judging and poses implicit questions: From what position of non-complicity do you judge? How can you acknowledge your complicity without undermining the grounds of your own judgement; after all, who are you to judge? And how can you not judge?

Equiano turns one of his opponents' weapons against them, for generalised complicity is precisely what the pro-slavery argument mobilises. Equiano provides an antidote to it, not by retreating to sanctimony (saintliness) nor by conceding general sinfulness (tyranny) but rather by offering the reader participation in contradiction rather than resolution or transcendence. What is achieved by this can be appreciated by comparing Thomas Pringle's strategy in his editor's notes to the The History of Mary Prince Related by Herself (1831).

Attempting to bolster slave Mary Prince's credibility and give credence to her history of abuse, Pringle attempts to discredit those attempting to discredit Prince as a 'despicable tool' (MacQueen 1831: 755) of the anti-slavery lobby. Against what he terms 'colonial special pleading' Pringle appeals to witnesses and to 'the reader's reflections', to 'natural affection' (in Prince 1831: 34, 19. 9). The reader is offered the opportunity to be on the side of the angels: 'The facts there stated must necessarily rest entirely, - since we have no collateral evidence, - upon their intrinsic claims to probability, and upon the reliance the reader may feel disposed, after perusing the foregoing pages, to place on her veracity' $(31)^{27}$. Pringle goes as far as to say that the guilt or innocence of those accused by Mary Prince is secondary to the goal of immediately abolishing colonial slavery. Or rather, guilt is a foregone conclusion since they are part of a reprehensible system, 'the true spirit of the slave system' (30).

Pringle's attempt to lend credibility to Mary Prince's testimony ends by dismissing the need for proof: 'suppose the whole of her own statement to be false, and even the whole of her conduct since she came under our

27 'It bears in my judgement the genuine stamp of truth and nature' (Joseph Phillips, of Antigua, in Prince 1831:26). 'Our best weapon against them is not to marshal facts, of which they are truly managers, but passion. Passion is our hope and strength, a very present help in trouble' (Achebe 1987: 3839). 


\section{Shane Moran}

observation to be a tissue of hypocrisy; - suppose all this - and leave the negro woman as black in character as in complexion - yet it would not affect the main facts' (29). The fate of the individual is secondary to the greater cause - here the justification or condemnation of slavery which is accused of sacrificing individuals to a greater cause, profit - for it is the system which is on trial (see Thomas 2005).

Forty years earlier Equiano aimed at the same goal but adopted a different strategy. With the abolition of the slave trade accomplished, perhaps Pringle could afford to be more cavalier, sensing that history was on his side $^{28}$. How can one abolish the slave trade and yet retain slavery? Pringle's slide into abandoning the criteria of proof, or rather, taking that proof to be incontrovertible, is to cross the line into from moral outrager to mastery. As Ramsay wrote of a different character: 'he was too apt to let prejudice usurp the place of proof' (Ramsay 1784: 249) ${ }^{29}$. Equiano's textual strategy offers a more demanding process for the reader. There is no redemptive transcendence in Equiano's world, no opting out by way of denunciatory salvation. But there is a correct interpretation, and, by implication, a correct course of action. To what degree the reader knowingly participates in the economy of contamination will affect the degree to which the question of Equiano's African origin is felt to determine the truthfulness of his narrative ${ }^{30}$. As he writes after having referenced Anthony Benezet and Thomas Clarkson (but not Wesley):

${ }^{28}$ Making the economic case for slavery and against what he called 'this anticolonial fungus', James MacQueen also noted the censorship of newspapers imposed on the West Indies under Benjamin D'Urban: 'Abstinence from all comments on the slave question, except such as are calculated to promote the measure recommended by His Majesty's government, and sanctioned by Parliament' (1831: 751: 756). Equiano contributed to that shift in forces, with the slavers on the back foot.

29 Ramsay is referring to Quashi's master from the fateful tale that encapsulated the evils of slavery. Tobin takes time to rebut this story (1785: 165-166). See also Joseph Addison, The Spectator (1711).

${ }^{30}$ On the evidence of a letter, written at Equiano's request and reproduced at the end of The Interesting Narrative, historian Simon Schama concludes that 'Equiano had gone all the way back to his own origins and the source of the evil, West Africa, where he served as an unordained chaplain and preacher 
I hope the reader will not think I have trespassed on his patience in introducing myself to him with some account of the manners and customs of my country. They had been implanted in me with great care, and made an impression on my mind, which time could not erase, and which all the adversity and variety of fortune I have since experienced served only to rivet and record; for, whether the love of one's country be real or imaginary, or a lesson of reason, or an instinct of nature, I still look back with pleasure on the first scenes of my life, though that pleasure has been for the most part mingled with sorrow (11).

Is Equiano signalling that his memoir is a mix of memory and imagination, reason and instinct? An 'implanted' or transplanted hybrid of childhood memory augmented and supplemented by subsequent experience/reading? Or has his childhood memory supplemented his reading?

Whatever the readers' answer to these questions it is difficult to forget that to maintain the importance of verifiability and factuality in an area that militates against verification is to invite bias. The testimony of Equiano is not 'sustained by a cloud of witnesses' (Garrison 1845: 8) that attend, for example, Frederick Douglass' narrative. It is in this instance just to side with one side of the dispute. After all, even Kant concedes that it is permissible to lie to someone who aims to maliciously use my truthfulness, hence 'the concept of the necessary lie' (Kant 1997: 204) ${ }^{31}$. Equiano foregrounds the equivocal nature of his moral position, that is to say, his moral judgement and by implication, the judgement of the reader.

We shall see that Equiano's strategy, far from muddying the waters

to Governor Matthias Macnamara at Cape Coast Castle' (2006: 167). The author of the letter on which Schama basis his claim for the African origin of Equiano is described by Vincent Carretta: 'Macnamara had been lieutenant governor of Senegambia in 1774 and governor in November 1775, but he was not a well-liked man, and as an administrator he was arrogant, self-important, impolitic and deceitful' (2005: 198).

${ }^{31}$ For 'if, in all cases, we were to remain faithful to every detail of the truth, we might often expose ourselves to the wickedness of others, which wanted to abuse out truthfulness' (Kant 1997: 204). See Nathan Nunn and Leonard Wantchekon (2011). 


\section{Shane Moran}

of moral judgement, has by the very act of surrendering moral binarism presented the reader with a telling choice. There can be no escape. None of us will come out of this intertextual history clean. As Equiano puts it, with the world being what it is rather than what it ought to be, 'none but the generous mind can judge' (61) the complicities one falls into. The condition of the slave 'doomed to be a witness and a participant' (Douglass 1845: 14) is mirrored by the reader as spectator who is likewise implicated. The universal and necessary categorical appeal to humanity is beset with impurity, and the scramble for moral superiority can be used against you. Equiano's text does not grant the reader the pose of objective adjudication, or recipient of uncontaminated truth. Rather the reader is implicated in the dialogic process of unfolding truth. When one is forced 'to set a powerless truth against a truthless power' (Foucault 2000: 33) do not be tempted by the prospect of the level moral playing field to blot out asymmetry of power.

\section{IV}

Doubtless, in a subject like this, where we must be satisfied with general accounts, probable conjectures, and analogical reasoning, a person inclined to take the other side may select many things to be objected to, many to be contradicted (Ramsay 1784: 254).

With this in mind, how do matters stand with our understanding of Kant's participation in the slavery debate on the side of the accused? Are we looking at Kant's all too human self-opacity? Did he have to embrace ignorance, thereby confirming Frantz Fanon's thesis that 'that consciousness has to lose itself in the night of the absolute, the only condition to attain consciousness of self' (1952: 102) ${ }^{32}$ before he could transcend it? Was transcendence into immersive parochiality - 'a matter of returning to something elementary, savage' (Wahl 1944: 69) - if not necessary, then unavoidable, perhaps even therapeutic? Certainly, the life of a thinker does not over-determine, negate

${ }^{32}$ Was Kant unknowingly peddling the default mode normative whiteness: '[T]think of “flesh-colored" crayons and band aids' (Mills 2018: 22)? 
or compromise their writing $\mathrm{s}^{33}$. But then neither can one dismiss or downplay the coexistence of these elements. They are not identical but neither are they unrelated, and it is the economy of this relationship that is of interest.

Kant changed his mind on matters of race, it is claimed. But the proslavery argument still stands, amenable to quotation in and out of context. Judging Kant seems more straightforward than judging Equiano for the latter was a victim, and spoke for other voiceless victims, of the slave trade. Kant, however, had only the prejudices and self-serving distortions of his time to contend with ${ }^{34}$. His statements were not forced on him, 'compelled to make by an unjust constraint, in order to prevent a threatened misdeed to himself or to another' (Kant 1797a: 612). He failed, at least (perhaps) at first, to come up to the standard he was promoting, and thereby helped to create racism in the process of (eventually) promoting its opposite, equality. To condemn Kant's contamination by prejudice is to risk appearing to exonerate oneself as his expense (see Flikshuh \& Ypi: 2014). Yet to defend him along the lines of 'Kant's own failure vindicates necessity of his philosophy' (Louden 2000: $105-106)^{35}$ is to yank a rather battered icon from the flames. Such an apologia is perilously close to the defect of optimism, condemned by Kant, that

${ }^{33}$ For the operation of the biographical reduction see Albert Memmi on Fanon's neurosis; the outsider's need to belong, the failure to belong that generated his work and texts, and his appeal to those who also wish to transform the world so that they will and extinguish themselves as outsiders at last (revolutionary romanticism) (1973: 9-39).

34 'My hypothesis is that Kant's cosmopolitanism - his search for a purpose in human history - made his racism even more pronounced because the racial inferiority he already recognized now struck him as an offence against all humanity, an offence against this very cosmopolitanism' (Bernasconi 2003: 18). I propose to address Kant's race thinking in more detail on another occasion.

35 'But Kant's theory is fortunately stronger than his prejudices, and it is the theory on which philosophers should focus .... The "redemption of the hopes of the past" [Horkheimer and Adorno, Dialectic of Enlightenment] is still a task worth pursuing, and we should no let ourselves be deceived by selfserving distortions of these hopes' (Louden 2000: 105-106). Nor should we be deceived by self-serving equations of criticism with an attack on the values of enlightenment. 
'regards exceptions as necessary defects ... just as a sailor sacrifices part of his cargo in order to save his ship and the rest of the cargo' (Kant 1759: 81).

To quickly distinguish Kant's liberal cosmopolitanism from our supposed cosmopolitanism on the grounds that today we are more attuned to the pitfalls of ethnocentrism and Eurocentrism risks eliding the striking continuities. A haunting question remains: Was racism necessary for the conception of cosmopolitanism?

Equiano's portrait of Essaka, and by implication Africa, reworks the idea of the primitive, which is to say he remains within the terms of the narrative continuum of progress from an origin. Essaka is an instituted society, with a legal system, private property (slaves) ${ }^{36}$, duties and sanctions. $\mathrm{He}$ is careful to avoid the depiction of African primitive community based primarily on collective possession. Slaves are the distillation of private property, which belongs to the family, or more precisely the (male) head of the family. Recall the emphasis on all the industry exerted to improve the blessings of nature by those habituated to labour and contributing to the common stock. Nothing in the depiction of African society derails Equiano's narrative paean to the desirability of private property as precondition of freedom. According to Equiano, not only is this origin shared, it is asynchronous for different stages can and do exist simultaneously. Africans are rational subjects bound by universal principles and lawfulness. And property ownership.

In short Africans have dignity, and so we might claim - in terms of the second version of the categorical imperative - they are deserving of respect as ends in themselves. They are part of general humanity, and, to

36 'Those prisoners which were not sold or redeemed we kept as slaves: but how different was their condition from that of the slaves in the West Indies! With us they do no more work than other members of the community, even their masters; their food, clothing and lodging were nearly the same as theirs, (except that they were not permitted to eat with those who were free-born); and there was scarce any other difference between them, than a superior degree of importance which the head of a family possesses in our state, and that authority which, as such, he exercises over every part of his household. Some of these slaves have even slaves under them as their own property, and for their own use' (Equiano 1789: 9). 
invoke the third version of the categorical imperative, part of the Kingdom of Ends. As Equiano puts it on the opening pages of his account, he seeks to promote 'the interests of humanity' (5), and his anti-slavery appeal to innate freedom accords with Kant's description of the only innate right: 'Freedom (independence from being constrained by another's choice), insofar as it can coexist with the freedom of every other in accordance with a universal law, is the only original right belonging to every man by virtue of his humanity' (1797b: 393). This is a principle, a concept, as well as a feeling of duty to the moral law without which there could be no moral law.

The Critique of Practical Reason (1788) explains this relationship between principle and feeling as regards the moral law under the heading 'Doctrine of the Method of Pure Practical Reason'. Kant emphasises that such an explanation of method, unlike other such explanations, cannot hope to provide clarity by delineating pure practical principles out of which a system could be constructed. Rather such a discussion of moral law follows 'the way in which one can make objectively practical reason subjectively practical' (1788b: 261). Even the limited appeal that legality has must be grounded in a subjective feeling for virtue, otherwise 'everything would be sheer hypocrisy; the law would be hated or even despised, though still observed for the sake of one's own advantage' (261). Following the law would be merely following 'the machinery of its police, guided only by what was done without troubling [ourselves] about the motives for which it was done'. This is not to say that moral education does not use its own 'machinery, these leading strings' up to a point that 'teaches the human being to feel his own dignity' (262), but only up to a point.

Yet this 'receptivity to pure moral interest' (262) must not remain at the level of feeling:

In our times, when one hopes to have more influence on the mind through melting, tender feelings or high-flown, puffed-up pretensions, which make the heart languid instead of strengthening it, than by a dry and earnest representation of duty, which is more suited to human imperfection and to progress in goodness, it is more necessary than ever to direct attention to this method (1788b: 265).

Intensity of feeling is transitory and does not lead to concerted action. Only principles built on concepts and their representation considered 'in relation 
to human beings and to the individual human being' (266) can provide the basis for duty in conformity with the moral law. Kant proffers an example which, as part of the machinery and leading strings of instruction, is purely a means to an end:

Let us now see in an example whether there is more subjective moving force as an incentive if an action is represented as a noble and magnanimous one than if it is represented merely as duty in relation to the earnest moral law. The action by which someone tries with extreme danger to his life to rescue people from a shipwreck, finally losing his own life in the attempt, will indeed be reckoned, on one side, as duty but on the other and even for the most part as a meritorious action; but our esteem for it will be greatly weakened by the concept of duty to himself, which seems in this case to suffer some infringement (1788b: 266).

Duty to himself as an example of humanity and as a unique individual to preserve his own life. He is not obligated to sacrifice himself for others, and one must not confuse the feeling on his part that he ought to with duty to the moral law. Kant adds that a person who lays down his life might on the face of it be a better example of duty to moral law, except that to do this of one's own accord is to offer up an example that will be dangerous to the nation one wishes to save if others imitate it.

Whereas Kant proposes clarify the conflict between duty and inclination, Equiano confesses to 'struggling between inclination and duty' (61). The reader is solicited to judge with 'a generous mind', which I take to be one that does not assume moral superiority. Pringle makes the same pitch on behalf of Mary Prince, appealing to a shared sense of moral and emotional superiority ('natural affection'), and opens himself to the charge of sanctimony. But what of that, if his cause was just? It is not irrelevant that Pringle's argument that whatever the untruths of Mary's (and his own) account 'it gets things right at the level of basic principles and values' (Wood 2008: 12) echoes the defence of Kant. Equiano's text points to the aporetic structure articulated by $\mathrm{Kant}^{37}$.

${ }^{37}$ Geoffrey Bennington (2017) explores the aporias in Kant's treatment of the state of nature and law, necessity and freedom, and the concept of moral 
Equiano's account of abandoning fellow countrymen who drowned while fleeing the enslavement to which he brought them foreshadows Kant's discussion of ambiguity in respect of right in The Metaphysics of Morals:

In other words, there can be no penal law that would assign the death penalty to someone in a shipwreck who, in order to save his own life, shoves another, whose life is equally in danger, off a plank on which he had saved himself. For the punishment threatened by the law could not be greater than the loss of his own life. A penal law of this sort could not have the effect intended, since a threat of an ill that is still uncertain (death by a judicial verdict) cannot outweigh the fear of an ill that is certain (drowning). Hence the deed of saving one's life by violence is not to be judged inculpable (inculpabile) but only unpunishable (impunibile), and by a strange confusion jurists take this subjective impunity to be objective impunity (conformity with law) (1797b: 392).

Cannot Equiano also claim to have survived, even if others did not (and perhaps did not because he did)? Do the rescue and the abandonment recounted in The Interesting Narrative cancel each other out; if not for the victims then at least as regards Equiano's overall culpability?

Equiano presents us with a case 'in which a right is in question but for which no judge can be appointed to render a decision' (179: 390) - which might also be taken to mean that anyone can judge, although not with an absolute assurance of being in a rightful position to judge. The abyss between right of equity and right of necessity confronts the reader who is in the position of judge where no judgement is possible but where judgment is necessary (see Bennington 2017: 138-143). As soon as someone steps in to judge another, wrong is perpetuated in the name of justice because to judge is to claim rightness, to be beyond the general pervasive contamination of an unjust system, which is effectively to undermine the charge that the whole system is unjust. Who then is to judge?

Equiano ends his narrative by appealing to economic motives as he

duty. The latter is essential to the abolitionist argument, as of course is freedom, and I would also suggest that Equiano's portrait of the lawfulness of Essaka indicates the importance of the nature/culture distinction. 


\section{Shane Moran}

punts the plan to settle ex-slaves in Sierra Leone where they will exploit the resources of Africa for the benefit of the home market by opening up new markets to British manufactures ${ }^{38}$. While Kant's note on freedmen expresses scepticism regarding the automatic benefit of free labour for former slaves, Equiano tirelessly argues for its benefits over that of slavery ${ }^{39}$. Despite this difference, or rather perhaps because of it, they are both able to integrate economic concerns and moral concerns. Both appeal to individualism and freedom, rights and duties, labour and development: moral economy as political economy (see Berry 2010). This is the thread that runs through the antislavery argument for the sacrifice of self-interest and against '[d]isregard of the Right of Mankind, and the feelings of humanity' (Benezet 1762: $12)^{40}$.

38 See Ottabah Cugoano on the Sierra Leone project: 'This prospect of settling a free colony to Great-Britain in a peaceable alliance with the inhabitants of Africa at Sierra Leona, has neither altogether met with the credulous approbation of the Africans here, nor yet been sought after with any prudent and right plan by the promoters of it' (1787: 139-140; and see Williams 1977: 40).

39 In this Equiano follows Benezet's argument for ex-slaves 'to become profitable Members of Society' as abolishing slavery altogether will increase the opportunity of those whose labour is undercut by slaves (1762: 70, 79; and see 33). By 1845 one anti-slavery observer could record that facts had discredited the argument for the economic benefit of free labour: 'I remember that, in 1838, many were waiting for the results of the West India experiment, before they could come into our ranks. Those "results" have come long ago; but, alas! few of that number have come with them, as converts. A man must be disposed to judge of emancipation by other tests than whether it has increased the produce of sugar, - and to hate slavery for other reasons than because it starves men and whips women, - before he is ready to lay the first stone of his anti-slavery life' (Phillips 1845: 9).

40 'Humanity and benevolence are fine pretences; but interest prompted him [Ramsay]' (Letter from the Vestry-Men and Church Warden of the Parish Church of St. Christopher [Saint Kitts] in Tobin 1785: 162). For his part Ramsay advised 'to contract an intimacy with them [slaves], to enter into their little interests, to hear patiently their doubts and complaints, to condescend to their weakness and ignorance, to lead them on slowly and 


\section{Conclusion}

One need only consider, for example, the actions which take place unnoticed within us when we read (Kant 1763: 228).

The key lesson to draw from Kant's aside on slavery, and his more extensive treatment of race, is that promotion of human rights can coexist with the proslavery principle of economic productivity and force ${ }^{41}$. Indeed, to reissue the Olympian phrase of The Great Reset, humans practice labour under moral considerations, and require constant vigilance.

The case of Equiano shows that treating all equally - requiring incontrovertible evidence for his claims - can reinforce inequality. In other words, the plutocratic slave holders and their spokesmen are not to be granted the presumption of innocence because they are in a dominant position. If there are reports of human suffering, they must be verified. Dismissal of such reports indicates, at best, negligence or callousness, and, at worst, collusion or even conspiracy. The spectacle of disproportionate power provokes a feeling for justice that is itself contaminated with injustice. Equality must be tempered with equity. The receptive reader is offered a mode of reflective self-formation on the way to being 'able to transcend the limits of merely personal experiences to identify general truths' (Carretta 2010: 93). The narrative evokes a necessarily subjective feeling of respect for the moral law that confirms the latter's objectivity. However much one must guard against lapsing into visionary enthusiasm by way of a feeling that purports to be the basis of knowledge, one must also guard against being deceived by blind confidence in the pretenses of reason. What looks like a discourse on economics may in fact be a sermon on duty, and vice versa, that defines ethical choice in these terms ${ }^{42}$.

gently, to exhort them affectionately, to avoid carefully magisterial threatenings and commands' (Ramsay 1784: 164).

${ }^{41}$ See Foucault on 'a general scheme, a great mechanism of transformation: How can men's time and their bodies, their lives, be made into something that is productive force?' (2000: 85).

${ }^{42}$ With this in mind, the following observation is timely reminder of the context in which the anti-slavery lobby won their fight for freedom: "The same elites that successfully removed the national blemish of the slave trade 
Setting Kant next to Equiano provides a glimpse of the process of abstraction and universalisation integral to reason, and the limits of protest and dissent; what Frederick Douglass called 'obstacles and sinuousities' (1894: 756) of the public use of reason. Not only is the credibility of the advocate on the line, perception of the balance of forces at play informs the process of interpretation and the sifting of what Kant termed 'falsely inventtive powers of imagination [whereby] self-representations are regarded as perceptions' (1798a: 320). Clearly the lineaments of pro-slavery rebellion can be read in the origin of the modern discourse of human rights. Resistance to what the pro-slavery Tobin called 'the improvement and conversion of humanity' (1785: 143) is framed as selfish inclination. The moralising discourse of just deserts and social harmony (the greater good) has never lost its currency. Tobin's pro-slavery admonition to beware those brooding with their 'usual style of petulance' and distributing 'many chimerical proposals' (146) is also familiar.

Equiano's appeal to imagination and understanding illustrates the difficulty of challenging the vested interests that control the landscape of debate, information, and censorship; of controlling the narrative, as we now say. He was accused of spreading conspiracy theories and misleading narratives. From 1789 to 1894, Equiano attempted to circumvent the captured media of his day - powerful publications whose interests were aligned with the pro-slavery lobby - and address the public directly. He toured Britain and Ireland lecturing on slavery and promoting The Interesting Narrative. Equiano was gratified by the warm reception he received from all ranks, and particularly the 'strong and enduring working class support' (Bugg 2006: 1438) who saw parallels between their own experiences and that of slaves.

Today we face the possibility that the goal of (sustainable) economic productivity no longer depends (if ever it did) on the free labour and private property demanded by Equiano, but retains its attachment to force and coercion for the greater good. What if the perennial pro-slavery rebellion could harness the discourse of human rights and emancipation from poverty?

were able to neutralize a variety of social and political threats to their dominance. In effecting the prohibition of a distant evil, British rulers simultaneously pre-empted domestic agitation and forged a formidable new weapon of nationalist mobilization against the Napoleonic menace' (Drescher 1994: 139). 
In this hall of mirrors, where would Equiano, or Kant for that matter, stand?

\section{Postscript}

This essay was written during the latter half of 2020. Yesterday, February $9^{\text {th }}, 2022$, I received a reminder from Stephan Merganthaler on behalf of the World Economic Forum: 'Dear Shane, We couldn't help but notice that it's been a while since you've engaged with the Forum. To ensure you're up to date, here is a recap on all the things you've missed, including the Davos Agenda 2022, intelligence briefings, and feature updates' (Merganthaler 2022). Key takeaways from the Davos Agenda 2022 (17 - 21 January) are that while the current pandemic may well becoming endemic there is still a need for immunisation (vaccination), and that national governments have shown their strengths and weaknesses:

As the COVID-19 crisis unfolded, people turned to governments to protect the economy and society and mobilise a healthcare response, including vaccine rollout. While they demonstrated their power, their limitations also became apparent, needing the help of international pharmaceutical companies, which have since enjoyed a boost their image. There is some evidence for support of further strengthening of state intervention but whether that will continue once the pandemic ends or will carry to other crises like climate change is yet to be seen (Atkinson \& Page 2022).

And under the heading 'COVID-19 Lesson \#10: A Sustainable Future Requires Leadership', the Chief Knowledge Officers of Ipsos* conclude: 'The same leadership sought from the pandemic is sought in the fight against climate change, giving governments and businesses a clear mandate to act'. Concerns about mental health and anxiety are noted, and personal liberty and freedom repackaged as 'personal health and safety and financial and health worries'.

*'Ipsos Group is a multinational market research and a consulting firm with headquarters in Paris, France. It conducts market research on advertising, marketing, media, public opinion, and social research' (World Economic Forum 2022). 


\section{References}

Achebe, C. [1964] 1976. The African Writer and the English Language. In Achebe, Chinua. Morning Yet on Creation Day. New York: Anchor Press/ Doubleday.

Achebe, C. 1987. Anthills of the Savannah. Johannesburg: Heinemann.

Achebe, C. [2009] 2011. Recognitions. In Achebe, Chinua. The Education of a British Protected Child. London: Penguin Classics.

Addison, J. 1711. The Spectator 215. Tuesday, November 6. Available at; https://www.fulltextarchive.com/pdfs/The-Spectator-Volume-2-.pdf; https://doi.org/10.1093/oseo/instance.00045661

Armistead, W. 1848. A Tribute to the Negro: Being a Vindication of the Moral, Intellectual, and Religious Capabilities of the Coloured Portion of Mankind; with Particular Reference to the African Race. Manchester: William Irwin, 1848. Available at: https://archive.org/details/tributefornegrob00armi

Atkinson, S. \& B. Page 2022. 10 COVID-19 Lessons that will Change the Postpandemic Future. World Economic Forum, January 13. Available at: https://www.weforum.org/agenda/2022/01/ten-covid19-lessons-fromthe-pandemic-ipsos

Baucom, I. 2005. Specters of the Atlantic: Finance Capital, Slavery, and the Philosophy of History. Durham: Duke University Press. https://doi.org/10.1515/9780822387022

Benezet, A. 1762. A Short Account of that Part of Africa Inhabited by the Negroes. ${ }^{\text {nd }}$ Enlarged Edition. Philadelphia: W. Dunlap. Available at: https://archive.org/details/shortaccountofth00benerich

Bennington, G. 2017. Kant on the Frontier: Philosophy, Politics, and the Ends of the Earth. New York: Fordham University Press. https://doi.org/10.5422/fordham/9780823275977.001.0001 PMid:28332677

Bernasconi, R. 2002. Kant as an Unfamiliar Source of Racism. In Ward, J.K. \& T.L. Lott (eds.): Philosophers on Race: Critical Essays. Oxford: Blackwell Publishers.

https://doi.org/10.1002/9780470753514.ch8

Bernasconi, R. 2003. Will the Real Kant Please Stand Up: The Challenge of Enlightenment Racism to the Study of the History of Philosophy. Radical Philosophy 117, January/ February: 13 - 22. 
Bernasconi, R. 2019. Ottabah Cugoano's Place in the History of Political

Philosophy: Slavery in the Philosophical Canon. In Hull, G. (ed.):

Debating African Philosophy: Perspective on Identity, Decolonial Ethics and Comparative Philosophy. Abingdon: Routledge.

https://doi.org/10.4324/9780429438189-2

Berry, C.J. 2010. Adam Smith's Moral Economy. The Kyoto Economic

Review 79, 1, June: 2 - 15.

Brennan, T. 1997. At Home in the World: Cosmopolitanism Now.

Cambridge, MA: Harvard University Press.

Bugg, J. 2006. The Other Interesting Narrative: Olaudah Equiano's Public Book Tour. PMLA 121, 5, October: $1424-1442$.

https://doi.org/10.1632/pmla.2006.121.5.1424

Carretta, V. 2005. Equiano, the African: Biography of a Self-Made Man. Athens: University of Georgia Press.

https://doi.org/10.1057/9780230277106_6

Carretta, V. 2010. Equiano's Paradise Lost: The Limits of Allusion in

Chapter Five of The Interesting Narrative. In Kaplan, C. \& J. Oldfield (eds.): Imagining Transatlantic Slavery. London: Palgrave Macmillan.

Caygill, H. 1989. The Art of Judgement. Oxford: Basil Blackwell.

Chuku, G. 2013. Olaudah Equiano and the Foundation of Igbo Intellectual Tradition. In Chuku, G. (ed.): The Igbo Intellectual Tradition: Creative Conflict in African and African Diasporic Thought. New York: Palgrave Macmillan.

https://doi.org/10.1057/9781137311290_2

Clarkson, T. [1788] 1808. An Essay on the Slavery and Commerce of the Human Species, Particularly the Africa. London: Longman, Hurst, Rees and Orme. Available at:

https://archive.org/details/essayonslaveryco00clar

Cugoano, Q.O. 1787. Thoughts on the Evil and Wicked Traffic of the Slavery and Commerce of the Human Species, Humbly Submitted to the Inhabitants of Great Britain, by Ottoba Cugoano, A Native of Africa. London, 1787. Available at: Thoughts and sentiments on the evil and wicked traffic of the slavery: and commerce of the human species, humbly submitted to the inhabitants of Great-Britain, by Ottobah Cugoano, ... (umich.edu)

Derrida, J. 1996. Archive Fever: A Freudian Impression. Prenowitz, E. (trans.). Chicago: The University of Chicago Press. 
https://doi.org/10.2307/465144

Dodsworth, L. 2021. State of Fear: How the UK Government Weaponised Fear During the COVID-19 Epidemic. London: Pinter and Martin.

Douglass, F. [1894] 1999. Why is the Negro Lynched? In Foner, P.S. \& Y.

Taylor (eds.): Frederick Douglass: Selected Speeches and Writings.

Chicago: Lawrence Hill Books.

Drescher, S. 1994. Whose Abolition? Popular Pressure and the Ending of the British Slave Trade. Past \& Present 143, May: 136-166.

https://doi.org/10.1093/past/143.1.136

Equiano, O. 1789. The Interesting Narrative of the Life of Olaudah Equiano, or Gustavus Vassa, the African. Written by Himself. London. Available at: http://www.gutenberg.org/files/15399/15399-h/15399-h.htm

Equiano, O. [1788] 2007. Letter to James Tobin, January 28, 1788 [The

Public Advertiser]. In Allison, R.J. (ed.): The Interesting Life of Olaudah Equiano, Written by Himself. New York: Bedford/ St. Martin's.

Eze, E. 1995. The Color of Reason: The Idea of 'Race' in Kant's Anthropology. In Faull, K.M. (ed.): Anthropology and the German Enlightenment: Perspectives on Humanity. Lewisburg, PA: Bucknell University.

Eze, E. (ed.). 1997. Race and the Enlightenment: A Reader. Oxford: Blackwell Publishers.

Fanon, F. [1952] 1986. Black Skin, White Masks. Markmann, C.L. (trans.). London: Pluto Press.

Flikshuh, K. \& L. Ypi (eds.). 2014. Kant and Colonialism: Historical and Critical Perspectives. Oxford: Oxford University Press.

https://doi.org/10.1093/acprof:oso/9780199669622.001.0001

Foucault, M. 2000. Truth and Juridical Forms. In Faubion, J.D. (ed.). Hurley, Robert et al. (trans.); Power. Volume 3 of Essential Works of Foucault 1954-1984. New York: The New Press.

Francklyn, G. 1789. AN ANSWER TO THE REV. MR. CLARKSON'S ESSAY ON THE Slavery and Commerce of the Human Species, Particularly the African; IN A SERIES OF LETTERS, FROM A GENTLEMAN IN JAMAICA TO HIS FRIEND IN LONDON: WHEREIN many of the Mistakes and Misrepresentations of $\mathrm{Mr}$. Clarkson are Pointed out, BOTH WITH REGARD TO The Manner in which that Commerce is Carried on the Africa, AND the Treatment of 
Slaves in the West Indies, SHEWING, AT THE SAME TIME, The Antiquity, Universality, and Lawfulness of Slavery, as ever having been one of the States and Conditions of Mankind. London. Available at: https://archive.org/details/ananswertorevmr00frangoog

Freeman, A. \& B. Kagarlitsky (eds.). 2004. The Politics of Empire: Globalisation and Crisis. London: Pluto Press.

Garrison, W.L. 1845. Preface. In Douglass, F. (ed.): Narrative of the Life of Frederick Douglass, An American Slave. Boston: The anti-Slavery Office.

Gregoire, H. [1808] 1996. On the Cultural Achievement of Negroes. Cassirer, T. \& F. Brière. Amherst: University of Massachusetts Press. Available at:

https://archive.org/details/onculturalachiev00greg/page/104/mode/2u $\mathrm{p}$ ?q=equiano

Guyer, P. 2007. Translator's Introduction. 'Observations on the Feeling of the Beautiful and the Sublime'. In Zöller, G. \& R.P. Louden (eds.): Kant Immanuel: Anthropology, History, and Education. Cambridge: Cambridge University.

https://doi.org/10.1017/CBO9780511791925.004

Guyer, P. (ed.). 2016. Virtues of Freedom. Selected Essays on Kant. Oxford: Oxford University Press.

https://doi.org/10.1093/acprof:oso/9780198755647.001.0001

Jameson, F. 2005. Fear and Loathing in Globalization. Archaeologies of the

Future: The Desire Called Utopia and Other Science Fictions. London:

Verso, 2003, 384-392.

Johnson, S.A. 2015. African American Religions, 1500-2000: Colonialism,

Democracy, and Freedom. New York: Cambridge University Press. https://doi.org/10.1017/CBO9781139027038

Kant, I. [1759] 1992. An Attempt at Some Reflections on Optimism. Appendix: Three Manuscript Reflections on Optimism. In Walford, D. \& R. Meerbote (eds.): Theoretical Philosophy, 1755 - 1770. Cambridge: Cambridge University Press.

Kant, I. [1763] 1992. Attempt to Introduce the Concept of Negative Magnitudes into Philosophy. In Walford, David \& Ralf Meerbote (eds.): Theoretical Philosophy, 1755 - 1770. Cambridge: Cambridge University Press.

https://doi.org/10.1017/CBO9780511840180 
Kant, I. [1781/87] 1998. Critique of Pure Reason. In Guyer, P. \& A.W. Wood. Cambridge: Cambridge University Press. https://doi.org/10.1017/CBO9780511804649

Kant, I. [1784a] 2007. Idea for a Universal History with a Cosmopolitan Aim. In Zöller, G. \& R.P. Louden. Wood, Allen W. (trans.). Anthropology, History, and Education. Cambridge: Cambridge University.

Kant, I. [1784b] 1996. An Answer to the Question: What is Enlightenment? In: Gregor, M.J. (ed. \& trans.). Practical Philosophy. Cambridge: Cambridge University Press.

Kant, I. [1785] 1996. Groundwork of the Metaphysics of Morals. In Gregor, M.J. (ed. \& trans.). Practical Philosophy. Cambridge: Cambridge University Press.

Kant, I. [1788a] 2007. On the Use of Teleological Principles in Philosophy. In Zöller, G. \& R.P. Louden (eds.). Wood, Allen W. (trans.): Anthropology, History, and Education. Cambridge: Cambridge University.

Kant, I. [1788b] 1996. Critique of Practical Reason. In Gregor, M.J. (ed. \& trans.): Practical Philosophy. Cambridge: Cambridge University Press. https://doi.org/10.1017/CBO9780511813306.010

Kant, I. [1803] 2007. Lectures on Pedagogy. In Zöller, G. \& R.P. Louden. Wood, A.W. (eds.). Louden, R.B. (trans.): Anthropology, History and Education. Cambridge: Cambridge University.

Kant, I. 1790. Critique of Judgement. Pluhar, W.S. (trans.). Indianapolis: Hackett Publishing.

Kant, I. [1792] 1992. The Dohna-Wundlacken Logic. Logic According to the Lectures of Professor Kant in the Summer Semester, 1792. In Young, J.M. (ed. \& trans.): Lectures on Logic. Cambridge: Cambridge University Press.

Kant, I. [1797a] 1996. On the Supposed Right to Lie from Philanthropy. In Gregor, M.J. (ed. \& trans.): Practical Philosophy. Cambridge: Cambridge University Press. https://doi.org/10.1017/CBO9780511813306.014

Kant, I. [1797b] 1996. The Metaphysics of Morals. In Gregor, M.J. (ed. \& trans,): Practical Philosophy. Cambridge: Cambridge University Press, https://doi.org/10.1017/CBO9780511813306.013

Kant, I. 1798a. Anthropology from a Pragmatic Point of View. In Zöller, G. \& R.P. Louden (eds.). Wood, A.W. (trans.): Anthropology, History, and 
Education. Cambridge: Cambridge University.

Kant, I. [1798b] 1997. The Conflict of the Faculties (Der Streit der

Facultäten). Gregor, M.J. (ed. \& trans.). USA: Abaris Books.

Kant, I. 1997. Moral Philosophy: Collins's Lecture Notes [1784 - 1785]. In

Heath, P \& J.B. Schneewind. Heath, P. (trans.): Lectures on Ethics.

Cambridge: Cambridge University Press.

https://doi.org/10.1017/CBO9781107049512

Losurdo, D. [2019] 2020. Nietzsche, the Aristocratic Rebel: Intellectual

Biography and Critical Balance-Sheet. Benton, G. (trans.). Leiden: Brill. https://doi.org/10.1163/9789004270954

Louden, R.P. 2000. Kant's Impure Ethics: From Rational Beings to Human Beings. New York: Oxford University Press.

Lyotard, J-F. 2009. Enthusiasm: The Kantian Critique of History. Van Den

Abbeele, G. (trans.). California: Stanford University Press.

MacQueen, J. 1831. The Colonial Empire of Great Britain. Letter to Earl

Grey, First Lord of the Treasury. Blackwood's Edinburgh Magazine 187, November: 744 - 764.

Memmi, A. 1973. The Impossible Life of Frantz Fanon. In Cassirer, T. \& G. Michael Twomey (trans.). The Massachusetts Review 14, 1, Winter: 939.

Merganthaler, S. 2022. Personal Email Communication, 9 February 2022.

Mills, C.W. 2018. Black Radical Kantianism. Res Philosophica 95, 1, January: 1 - 33. Available at: https://doi.org/10.11612/resphil.1622;

https://simpsoncenter.org/sites/simpson/files/Charles-Mills-Black-

Radical-Kantianism.pdf

Nancy, J-L. [1976] 2008. The Discourse of the Syncope: Logodaedalus. Anton, S. (trans.). California: Stanford University Press.

Nunn, N. \& L. Wantchekon 2011. The Slave Trade and the Origins of Mistrust in Africa. American Economic Review 101, 7: 3221 - 3252. https://doi.org/10.1257/aer.101.7.3221

Phillips, W. 1845. Letter from Wendell Phillips, Esq. Boston, April 22 ${ }^{\text {nd }}$, 1845. In Douglass, F.: Narrative of the Life of Frederick Douglass, An American Slave. Boston. Available at:

https://archive.org/details/douglasfred00dougrich

Philmore, J. 1760. Two Dialogues on the Man-trade. London. Available at: https://archive.org/details/TwoDialoguesOnTheMan-tradelondon 1760 Prince, M. 1831. The History of Mary Prince, A West Indian Slave, Related 
by Herself. With a Supplement by the Editor. To which is Added the Narrative of Asa-Asa, A Captured African. London: F. Westley and A. H. Davis. Available at:

https://docsouth.unc.edu/neh/prince/prince.html

Ramsay, J. 1784. An Essay on the Treatment and Conversion of African Slaves in the British Sugar Colonies. London: James Phillips. Available at: An essay on the treatment and conversion of African slaves in the British sugar colonies : Ramsay, James, 1733-1789 : Free Download, Borrow, and Streaming: Internet Archive

Satia, P. 2008. Spies in Arabia: The Great War and the Cultural Foundations of Britain's Covert Empire in the Middle East. Oxford: Oxford University Press.

https://doi.org/10.1093/acprof:oso/9780195331417.003.0009

Schama, S. 2006. Rough Crossings: The Slaves, The British, and the American Revolution. HarperCollins.

Schwab, K. 2016. The Fourth Industrial Revolution. World Economic Forum. Available at: https://www.weforum.org/agenda/2016/01/thefourth-industrial-revolution-what-it-means-and-how-to-respond/

Schwab, K. \& T. Malleret 2020. COVID-19: The Great Reset. Geneva: The World Economic Forum.

Schwab, K. 2020a. The Great Reset. World Economic Forum. Available at: The Great Reset | World Economic Forum (weforum.org)

Serequeberhan, T. 2006. The Critique of Eurocentrism. In Ashcroft, B., G. Griffths \& H. Tiffin (eds.): The Post-Colonial Studies Reader. $2^{\text {nd }}$ Edition. Oxford: Routledge.

Thomas, S. 2005. Pringle v. Cadell and Wood v. Pringle: The Libel Cases over The History of Mary Prince. Journal of Commonwealth Literature 40, 1: 113-135.

https://doi.org/10.1177/0021989405050668

Thomas, W.H. 1901. The American Negro. What He Was, What He is, and What He May Become - A Critical and Practical Discussion. New York: The Macmillan Company. Available at:

https://archive.org/details/americannegrowh00thomgoog; https://doi.org/10.5479/sil.1064194.39088018649459

Tobin, J. 1785. Cursory Remarks upon the Reverend Mr. Ramsay's Essay on the Treatment and Conversion of African Slaves in the Sugar Colonies. Bristol. 
Turnbull, G. 1786. An Apology for Negro Slavery; or, the West-India Planters Vindicated from the Charge of Inhumanity. London: Stewart and Stevenson.

Vial, T. 2016. Modern Religion, Modern Race. Oxford: Oxford University Press.

https://doi.org/10.1093/acprof:oso/9780190212551.001.0001

Wahl, J. 1944. Human Existence and Transcendence. Hackett, W.C. (ed. and trans.). Notre Dame: University of Notre Dame Press.

Wesley, J. [1791] 1931. John Wesley to William Wilberforce, February $24^{\text {th }}$, 1791. Telford, J. (ed.): The Letters of John Wesley. Volume 8. London: Epworth Press. Available at: Letters Of The Rev John Wesley: Telford, John Ed. : Free Download, Borrow, and Streaming : Internet Archive Wesley, J. [1744] 1792. Thoughts Upon Slavery. 5 ${ }^{\text {th }}$ Edition. London: G. Paramore. https://archive.org/details/thoughtsuponslav00wesl

Williams, H. 1977. Kant's Concept of Property. The Philosophical Quarterly 27, 106, January: 32 - 40. https://doi.org/10.2307/2218926

Wood, A.W. 2008. Kantian Ethics. Cambridge: Cambridge University Press. Wood, A.W. 1999. Kant's Ethical Thought. Cambridge: Cambridge University Press.

World Economic Forum 2022. Ipsos. Ipsos $\mid$ World Economic Forum (weforum.org)

Zöller, G. \& R.P. Louden (eds.). 2007. Anthropology, History, and Education. Cambridge: Cambridge University Press.

Shane Moran English Studies University of Fort Hare South Africa SMoran@ufh.ac.za 